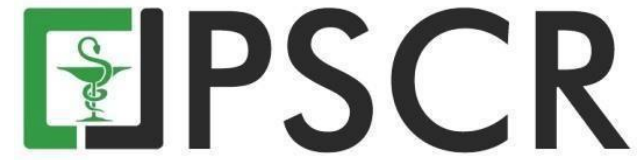

\title{
Faktor Risiko Musculoskeletal Pain pada Pasien Chronic Myeloid Leukemia (CML) dengan Kemoterapi Nilotinib di RSUD Dr. Moewardi
}

\author{
Rasmaya Niruri ${ }^{1 *}$, Eti Poncorini Pamungkasari ${ }^{2}$ dan Syifa Maulida Rahmah ${ }^{1}$ \\ ${ }^{1}$ Program Studi Farmasi, Fakultas Matematika dan Ilmu Pengetahuan Alam, Universitas Sebelas Maret, Jl. Ir. \\ Sutami 36A, Surakarta, Indonesia, 57126 \\ ${ }^{2}$ Program Studi Kedokteran, Fakultas Kedokteran, Universitas Sebelas Maret, Jl. Ir. Sutami 36A, Surakarta, \\ Indonesia, 57126 \\ *email korespondensi: rasmaya@ staff.uns.ac.id \\ Received 27 August 2020, Accepted 10 March 2021, Published 15 July 2021
}

Abstrak: Chronic Myeloid Leukemia (CML) merupakan penyakit mieloproliferatif yang ditandai dengan peningkatan sel mieloid dan ditemukan adanya kromosom Philadelphia yang disebabkan karena adanya translokasi respirok gen $B C R-A B L$. Nilotinib adalah Tyrosine Kinase Inhibitor (TKI) yang disetujui untuk pengobatan pasien dewasa yang baru di diagnosis CML dalam fase kronis (CML-CP) dengan kromosom Philadelphia positif $(\mathrm{Ph}+)$ atau pasien $\mathrm{Ph}+\mathrm{CML}$ yang resisten atau tidak toleran terhadap imatinib dalam fase kronis $(\mathrm{CP})$ atau fase dipercepat (AP). Pada beberapa studi menunjukkan bahwa nilotinib berkaitan dengan munculnya efek samping obat. Salah satu efek samping obat yang terjadi pada penggunaan nilotinib yaitu musculoskeletal pain. Penelitian ini bertujuan untuk mengetahui frekuensi terjadinya musculoskeletal pain dan menganalisis pengaruh faktor usia, Indeks Masa Tubuh (IMT), dan riwayat Diabetes Mellitus (DM) pada pasien CML dengan kemoterapi nilotinib di RSUD Dr. Moewardi. Penelitian dilakukan sebagai studi observasional dengan desain cross sectional pada 35 subyek pasien CML dengan kemoterapi nilotinib pada bulan Januari 2016 Maret 2019. Evaluasi dilakukan selama 1 tahun setelah subyek mendapatkan kemoterapi nilotinib dengan menggunakan rekam medis dan lembar pengumpul data.Hasil penelitian ini menunjukkan bahwa 13 pasien $(37,1 \%)$ mengalami musculoskeletal pain. Hasil evaluasi dengan Algoritma Naranjo yaitu 7 pasien masuk dalam kategori possible dan 6 pasien dalam kategori probable. Indeks Masa Tubuh (IMT) berpengaruh secara signifikan terhadap terjadinya musculoskeletal pain dengan nilai $p$ sebesar 0,041 , nilai Odds Ratio sebesar 7, dan Interval Kepercayaan 95\% sebesar 1,09-45,16. Sedangkan, faktor usia dan riwayat DM tidak berpengaruh secara signifikan terhadap terjadinya musculoskeletal pain.

Kata kunci: CML; TKI; Nilotinib; Musculoskeletal Pain

Abstract: Risk factors of musculoskeletal pain in Chronic Myeloid Leukemia (CML) patients with nilotinib chemotherapy in RSUD Dr. Moewardi. Chronic Myeloid Leukemia (CML) is a myeloproliferative disease that is characterized by the increase of myeloid cells and Philadelphia chromosome which is caused by the translocation of the $B C R-A B L$ gene. Nilotinib is an approved Tyrosine Kinase Inhibitor (TKI)for the treatment of adult patients newly diagnosed with CML in the chronic phase (CML-CP) with positive Philadelphia Chromosome $(\mathrm{Ph}+)$ or $\mathrm{Ph}+\mathrm{CML}$ patients who are resistant or intolerance to imatinib in the CPor accelerated phase (AP).One of the ADR that occur in the use of nilotinib is musculoskeletal pain. This study aims to determine the frequency of occurrence of musculoskeletal pain and analyze the influence of age factors, Body Mass Index (BMI), and history of Diabetes Mellitus (DM) in CML patients with nilotinib chemotherapy in RSUD Dr. Moewardi. The study was conducted as an observational study with cross sectional design on 35 subjects of CML patients with nilotinib chemotherapy in January 2016-March 2019. The 
evaluation was carried out for 1 year after subjects received nilotinib chemotherapy using medical records and data collection sheets. The results of this study showed that 13 patients $(37,1 \%)$ experienced musculoskeletal pain. The evaluation results usingNaranjo Algorithm are 7 patients in the possible category and 6 patients in the probable category. Body Mass Index (BMI) significantly influence the occurrence of musculoskeletal pain with $p$ value of 0,041, Odds Ratio of 7, and 95\% Confidence Interval of 1,09-45,16. Meanwhile, age and history of DM was not significantly influence the occurrence of musculoskeletal pain.

Keywords: CML; TKI; Nilotinib; Musculoskeletal Pain

\section{Pendahuluan}

Chronic Myeloid Leukemia (CML) merupakan suatu keganasan hematologis yang ditandai dengan translokasi antara lengan panjang kromosom 9 dan kromosom 22 yang terjadi dalam sel induk hematopoietik, serta mengarah pada pembentukan onkogen $B C R-A B L$ (Holyoake \& Vetrie, 2017). CML memengaruhi sekitar 1-2 orang per 100.000 orang dewasa per tahun. Data menunjukkan bahwa kejadian CML pada populasi Asia lebih rendah dibandingkan Kaukasia, tetapi memengaruhi populasi muda. Pusat penelitian di Indonesia mencatat median usia penderita CML adalah 34,67 tahun dan $61 \%$ berjenis kelamin laki-laki (Widyastuti et al., 2020). Insiden tersebut tidak berubah selama beberapa dekade terakhir dan meningkat seiring bertambahnya usia (Reksodiputro et al., 2015).

Terapi pengobatan CML telah terjadi perkembangan dari tahun ke tahun. Salah satu pengobatan CML di era sekarang yaitu menggunakan Tyrosine Kinase Inhibitor (TKI).TKI merupakan golongan obat untuk CML yang tertarget pada $B C R-A B L 1$ dan berkontribusi dalam menghambat aktivitas tirosin kinase (Hiwase et al., 2018). Obat-obatan golongan TKI antara lain imatinib, nilotinib, dan dasatinib. Nilotinib diketahui lebih kuat dan selektif daripada imatinib, hal itu ditunjukkan dari efektivitas yang lebih unggul dibandingkan dengan imatinib (Cortes et al., 2016). Signorovitch,et al (2014) menyatakan bahwa nilotinib memiliki tingkat MMR yang lebih besar dibandingkan dengan imatinib dan dasatinib. Pada penelitian terkait respon molekuler yang dinilai dalam 3 bulan menunjukkan bahwa nilotinib lebih baik dalam mencapai Molecular Response (MR) daripada dasatinib (Cortes et al., 2020).

Penggunaan kemoterapi nilotinib dapat menyebabkan munculnya efek samping obat atau disebut Adverse Drug Reactions (ADR). Salah satu ADR yang terjadi pada penggunaan TKI khususnya nilotinib yaitu musculoskeletal pain. Nilotinib dapat memengaruhi homeostasis otot dengan menghambat diferensiasi miogenik dan merangsang proliferasi myoblast. Pada studi klinis dengan pasien dewasa yang baru didiagnosis dengan CML $\mathrm{Ph}+$ dalam fase kronis, gejala musculoskeletal pain dilaporkan dalam satu tahun setelah penghentian nilotinib yaitu $24,7 \%$ berbanding pada tahun sebelumnya dengan pengobatan nilotinib sebesar $16,3 \%$. Sedangkan dalam studi klinis dengan pasien dewasa CML Ph+ dalam fase kronis pada pengobatan nilotinib dan sebelumnya diobati dengan imatinib, gejala 
musculoskeletal pain dilaporkan dalam satu tahun penghentian yaitu $42 \%$ berbanding dalam tahun sebelumnya dengan pengobatan nilotinib sebesar 14\% (Kota \& Atallah, 2019).

Pasien CML dengan kemoterapi nilotinib mempunyai kemungkinan besar untuk mengalami musculoskeletal pain. Musculoskeletal pain yang terjadi umumnya memiliki tingkat keparahan yang rendah. Namun,apabila menjadi kronis hal tersebut dapat berdampak pada kualitas hidup pasien dan kepatuhan pasien terhadap pengobatan. Pada era pengobatan TKI ini masih sedikit penelitian yang membahas secara mendalam mengenai efek musculoskeletal pain pada pasien CML dengan kemoterapi nilotinib dan belum ada juga penelitian yang membahas mengenai hal tersebut di RSUD Dr. Moewardi. Maka dari itu, peneliti ingin mengetahui frekuensi terjadinya musculoskeletal pain dan menganalisis pengaruh faktor usia, Indeks Masa Tubuh (IMT), dan riwayat Diabetes Mellitus (DM) terhadap terjadinya musculoskeletal pain pada pasien Chronic Myeloid Leukemia (CML) dengan kemoterapi nilotinib di RSUD Dr. Moewardi.

\section{Bahan dan Metode}

Penelitian yang dilakukan merupakan penelitian observasional dengan menggunakan desain cross sectional. Penelitian dilakukan pada bulan Maret - Juli 2020 dari persiapan penelitian, pengumpulan data, dan analisis data. Metode penelitian ini telah mendapatkan sertifikat laik etik dari Komisi Etik Penelitian Kesehatan RSUD Dr. Moewardi Surakarta dengan nomor surat 688/V/HREC/2020 disertai surat pernyataan menyimpan rahasia rekam medis yang disetujui oleh peneliti. Pengambilan sampel untuk data identifikasi musculoskeletal pain dilakukan dengan menggunakan data rekam medis pasien Chronic Myeloid Leukemia (CML) pada bulan Januari 2016 - Maret 2019 dan dilakukan pengamatan data dalam kurun waktu satu tahun. Penentuan besar sampel minimal untuk penelitian ini dihitung menggunakan rumus rule of thumbs dengan 3 variabel bebas yang diteliti yaitu usia, Indeks Masa Tubuh (IMT), dan riwayat Diabetes Mellitus (DM).

Pengambilan sampel menggunakan metode non probability sampling dengan teknik pengambilan sampel consecutive sampling. Data penelitian diperoleh dari rekam medis yang dicatat dalam lembar pengumpul data kemudian dilakukan analisis data. Analisis deskriptif dilakukan untuk mendeskripsikan frekuensi terjadinya musculoskeletal pain pada pasien Chronic Myeloid Leukemia (CML) dengan kemoterapi nilotinib. Analisis untuk mengidentifikasi faktor-faktor yang memengaruhi terjadinya musculoskeletal pain dilakukan dengan program SPSS Statistics 24.0 for Windows menggunakan uji Chi-Square bila memenuhi syarat (tidak ada sel yang mempunyai nilai expected kurang dari lima). Jika tidak memenuhi syarat, maka digunakan uji Fisher. Variabel yang dapat masuk ke dalam analisis multivariat dengan uji regresi logistik adalah variabel yang pada analisis bivariat memiliki 
nilai $\mathrm{p}<0,25$. Metode yang digunakan pada analisis regresi logistik yaitu metode backward LR (Dahlan, 2011).

\section{Hasil dan Pembahasan}

\subsection{Karakteristik pasien}

Pada penelitian ini didapatkan 35 pasien yang memenuhi kriteria inklusi dan eksklusi dari total populasi sebanyak 63 pasien. Berdasarkan distribusi usia, terdapat 7 pasien (20\%) berusia 18-35 tahun dan 28 pasien $(80 \%)$ berusia > 35 tahun. Hal ini sesuai dengan penelitian Kim, et al (2010), yang menyatakan bahwa usia rata-rata pasien yang didiagnosis dengan CML di wilayah Asia-Pasifik adalah di atas usia 35 tahun yaitu sekitar usia 45 tahun. Sementara di negara Barat usia rata-rata 20 tahun lebih tua, yaitu usia 65 tahun.Distribusi pasien berdasarkan jenis kelamin pada Tabel 1 menunjukkan bahwa pasien laki-laki berjumlah $23(65,71 \%)$ dan pasien perempuan berjumlah 12 (34,29\%). Berdasarkan distribusi jenis kelamin, diketahui pasien laki-laki memiliki prevalensi yang lebih besar dibandingkan dengan pasien perempuan. Hasil yang sama ditunjukkan pada penelitian yang dilakukan oleh Kim, et al (2010), yang menyatakan bahwa pasien CML di Asia-Pasifik lebih banyak ditemukan pada pasien laki-laki dibandingkan perempuan dengan perbandingan sebesar $3: 2$. Akan tetapi, pada penelitian sebelumnya dilaporkan bahwa musculoskeletal pain lebih sering terjadi pada pasien perempuan. Pada penelitian Molsted, et al (2012), melaporkan bahwa musculoskeletal pain lebih sering terjadi pada perempuan dibandingkan dengan laki-laki. Beberapa hasil penelitian menunjukkan bahwa jenis kelamin perempuan memengaruhi tingkat risiko terjadinya musculoskeletal pain pada pasien CML dengan pengobatan TKI (Yu et al., 2019).

Distribusi pasien berdasarkan Indeks Masa Tubuh (IMT) dikelompokkan menjadi nilai IMT $<25 \mathrm{~kg} / \mathrm{m}^{2}$ dan $\geq 25 \mathrm{~kg} / \mathrm{m}^{2}$ yang diukur berdasarkan data berat badan (dalam $\mathrm{kg}$ ) dibagi kuadrat tinggi badan (dalam meter) atau BB/TB ${ }^{2}$. Pada Tabel 1, terdapat 27 pasien $(77,14 \%)$ dengan nilai IMT $<25 \mathrm{~kg} / \mathrm{m}^{2}$ dan hanya 8 pasien $(22,86 \%)$ dengan nilai IMT $\geq 25 \mathrm{~kg} / \mathrm{m}^{2}$. Meskipun pada penelitian ini pasien dengan IMT $\geq 25 \mathrm{~kg} / \mathrm{m}^{2}$ lebih sedikit, akan tetapi perlu diketahui bahwa peningkatan berat badan dengan IMT tinggi telah dikaitkan dengan peningkatan risiko pengembangan keganasan. Hal itu ditunjukkan dengan bukti epidemiologi yang menunjukkan bahwa peningkatan berat badan dan obesitas adalah faktor risiko untuk beberapa kanker hematologi termasuk CML (Breccia et al., 2013). Dimana peningkatan berat badan dan obesitas tersebut dapat disebabkan karena faktor genetik yang diperburuk dengan gaya hidup yang tidak sehat (Williams et al., 2015). 
Tabel 1. Karakteristik pasien Chronic Myeloid Leukemia (CML) di RSUD Dr. Moewardi pada bulan Januari 2016 - Maret 2019 (N Total = 35).

\begin{tabular}{lcc}
\hline \multicolumn{1}{c}{ Karakteristik } & Jumlah (n) & Presentase (\%) \\
\hline Usia & 7 & \\
18-35 tahun & 28 & $20 \%$ \\
$\quad>35$ tahun & & $80 \%$ \\
Jenis Kelamin & 23 & \\
$\quad$ Laki-Laki & 12 & $65,71 \%$ \\
$\quad$ Perempuan & & $34,29 \%$ \\
Indeks Masa Tubuh (IMT) & 27 & \\
$\quad<25 \mathrm{~kg} / \mathrm{m}^{2}$ & 8 & $77,14 \%$ \\
$\quad \geq 25 \mathrm{~kg} / \mathrm{m}^{2}$ & & $22,86 \%$ \\
Riwayat Diabetes Mellitus (DM) & 3 & $8,57 \%$ \\
$\quad$ Memiliki riwayat DM & 32 & $91,43 \%$ \\
$\quad$ Tidak memiliki riwayatDM & & \\
Durasi Terapi Obat & 2 & $5,71 \%$ \\
$\quad<12$ bulan & 33 & $94,29 \%$ \\
$\quad \geq 12$ bulan & & \\
\hline
\end{tabular}

Distribusi pasien berdasarkan riwayat Diabetes Mellitus (DM) ini didominasi oleh pasien yang tidak memiliki riwayat DM dengan jumlah 32 pasien $(91,43 \%)$ dibandingkan dengan pasien yang memiliki riwayat DM dengan jumlah 3 pasien $(8,57 \%)$. Pasien CML yang memiliki riwayat DM bisa lebih rentan mengalami efek lain dari pengobatan nilotinib (Martino et al., 2017). Menurut penelitian Merashli, et al (2015), DM merupakan salah satu penyakit penyerta yang berpengaruh pada terjadinya musculoskeletal pain. Kondisi tersebut dapat mempengaruhi sendi, jaringan lunak, saraf, otot, atau tendon.Distribusi pasien berdasarkan durasi terapi obat pada Tabel 1 menunjukkan bahwa setelah dilakukan evaluasi selama 1 tahun sebanyak 33 pasien $(94,29 \%)$ mendapatkan kemoterapi nilotinib dengan durasi terapi $\geq 12$ bulan. Sedangkan sebanyak 2 pasien $(5,71 \%)$ telah mendapatkan kemoterapi nilotinib dengan durasi terapi $<12$ bulan.

\subsection{Kejadian musculoskeletal pain dengan kemoterapi nilotinib}

Pada penelitian ini, diketahui bahwa dari 35 pasien, pasien yang mengalami musculoskeletal pain lebih rendah daripada pasien yang tidak mengalami musculoskeletal pain dengan nilai presentase pasien yang mengalami musculoskeletal pain sebesar 37,1\% (13 pasien). Penelitian yang dilakukan oleh Hussain \& Shaikh (2015), menyatakan bahwa salah satu efek samping obat yang terjadi selama pengobatan nilotinib yaitu terjadinya berbagai jenis musculoskeletal pain. Keluhan otot sangat relevan pada pasien yang diobati dengan nilotinib. Keluhan otot ini sangat terkait dengan adanya kelelahan dan berkontribusi terhadap berkurangnya kontrol penyakit dan gangguan kualitas hidup. Meskipun mekanisme nilotinib yang menyebabkan keluhan otot kurang diketahui, akan tetapi disebutkan bahwa TKI begitu 
pula dengan nilotinib dapat mengganggu kerapatan otot dan fungsi otot pada tubuh(Janssen et al, 2019).

Penelitian ini menganalisis lebih lanjut efek penggunaan kemoterapi nilotinib terhadap musculoskeletal pain secara periodik setiap 3 bulan untuk mengetahui waktu paling dominan pasien mengalami musculoskeletal pain. Berdasarkan pada Tabel 2, diketahui bahwa kejadian musculoskeletal pain tidak memiliki perbedaan yang bermakna pada periode 1 (bulan ke 1 3) dan periode 4 (bulan ke 10 - 12). Kejadian musculoskeletal pain paling banyak terjadi pada periode 2 (bulan ke $4-6$ ) dengan $p$ value sebesar $0,001(p<0,05)$ dan pada periode 3 (bulan ke 7 - 9) dengan $p$ value sebesar 0,014 ( $p<0,05)$. Hal tersebut menunjukkan bahwa terdapat perbedaan yang bermakna pada terjadinya musculoskeletal pain di periode 2 dan 3.

Pada penelitian yang dilakukan oleh Nakamae, et al (2011), menyebutkan bahwa efek musculoskeletal pain termasuk nyeri otot dan nyeri sendi sering dilaporkan pada pengobatan nilotinib dengan waktu terjadi yaitu setelah 6 bulan terapi nilotinib. Waktu terjadinya efek tersebut lebih lama dikarenakan terjadinya musculoskeletal pain pada penggunaan nilotinib termasuk suatu late effect sehingga efeknya baru terjadi setelah beberapa bulan pengobatan. Hal tersebut juga ditunjukkan pada penelitian yang dilakukan oleh Hiwase, et al (2018) yang menyatakan bahwa pada penelitian selama 24 bulan dan dievaluasi secara periodik, pasien CML yang telah dialihkan pada pengobatan nilotinib mengalami berbagai efek samping obat termasuk musculoskeletal pain.

Tabel 2. Hasil evaluasi kejadian Musculoskeletal Pain secara periodik pada pasien CML dengan kemoterapi nilotinib. Keterangan: * menunjukkan hasil analisis uji Fisher.

\begin{tabular}{|c|c|c|c|c|c|c|}
\hline \multirow{2}{*}{\multicolumn{2}{|c|}{$\begin{array}{l}\text { Periode Kejadian } \\
\text { Musculoskeletal Pain }\end{array}$}} & \multicolumn{2}{|c|}{ Musculoskeletal Pain } & \multicolumn{2}{|c|}{$\begin{array}{c}\text { Tidak } \\
\text { Musculoskeletal Pain }\end{array}$} & \multirow{4}{*}{$\begin{array}{c}\text { p value* } \\
0,131\end{array}$} \\
\hline & & \multirow{2}{*}{$\begin{array}{l}\mathbf{N} \\
2\end{array}$} & \multirow{2}{*}{$\begin{array}{c}\% \\
100 \%\end{array}$} & \multirow{2}{*}{$\begin{array}{l}\mathbf{N} \\
0\end{array}$} & \multirow{2}{*}{$\begin{array}{c}\% \\
0 \%\end{array}$} & \\
\hline Periode 1 & $\mathrm{Ya}$ & & & & & \\
\hline (Bulan ke $1-3$ ) & Tidak & 11 & $33,3 \%$ & 22 & $66,7 \%$ & \\
\hline \multirow{2}{*}{$\begin{array}{l}\text { Periode } 2 \\
\text { (Bulan ke } 4-6)\end{array}$} & $\mathrm{Ya}$ & 6 & $100 \%$ & 0 & $0 \%$ & \multirow{2}{*}{0,001} \\
\hline & Tidak & 7 & $24,1 \%$ & 22 & $75,9 \%$ & \\
\hline \multirow{2}{*}{$\begin{array}{l}\text { Periode } 3 \\
\text { (Bulan ke } 7 \text { - 9) }\end{array}$} & $\mathrm{Ya}$ & 4 & $100 \%$ & 0 & $0 \%$ & \multirow{2}{*}{0,014} \\
\hline & Tidak & 9 & $29 \%$ & 22 & $71 \%$ & \\
\hline \multirow{2}{*}{$\begin{array}{l}\text { Periode } 4 \\
\text { (Bulan ke } 10-12 \text { ) }\end{array}$} & Ya & 1 & $100 \%$ & 0 & $0 \%$ & \multirow{2}{*}{0,371} \\
\hline & Tidak & 12 & $35,3 \%$ & 22 & $64,7 \%$ & \\
\hline Total & & 13 & $37,1 \%$ & 22 & $62,9 \%$ & \\
\hline
\end{tabular}

Penelitian sebelumnya melaporkan bahwa penghentian pengobatan dikaitkan dengan risiko efek musculoskeletal pain tingkat rendah dengan beberapa diantaranya mungkin mengalami kejadian yang bertahan lama. Pasien CML dapat mengalami musculoskeletal pain setelah penghentian pengobatan, dimana insiden kejadian musculoskeletal pain tersebut dapat 
pula menurun dari waktu ke waktu (Pulte et al., 2019). Musculoskeletal pain yang diklasifikasikan sebagai sindrom penarikan TKI dilaporkan pada $24,7 \%$ pasien yang berhenti menggunakan nilotinib. ADR ini sebagian besar terjadi pada kisaran waktu <1 hingga 6 bulan dengan median waktu terjadinya musculoskeletal pain yaitu 1 bulan (Kota \& Atallah, 2019).

Penelitian ini juga mengevaluasi lebih lanjut efek musculoskeletal pain menggunakan Algoritma Naranjo. Algoritma Naranjo berfungsi untuk menentukan apakah efek yang merugikan benar-benar disebabkan oleh obat atau faktor lain. Berdasarkan pada Tabel 3, diketahui bahwa dari 35 pasien, sebanyak 22 pasien (62,86\%) tidak mengalami musculoskeletal pain sehingga masuk dalam kategori skala probabilitas doubtful. Pasien yang mengalami musculoskeletal pain dalam kategori skala probabilitas possible sebanyak 7 pasien (20\%), artinya bahwa efek musculoskeletal pain yang dirasakan pasien kemungkinan disebabkan oleh kemoterapi nilotinib yang dikonsumsi pasien selama pengobatan. Sedangkan sebanyak 6 pasien $(17,14 \%)$ mengalami musculoskeletal pain dengan kategori skala probabilitas probable, yang artinya bahwa efek musculoskeletal pain yang dirasakan pasien besar kemungkinan disebabkan oleh kemoterapi nilotinib yang dikonsumsi pasien selama pengobatan. Pada penelitian yang dilakukan oleh Hiwase, et al (2018), diketahui bahwa efek dari nilotinib terbagi menjadi hematologis dan non-hematologis. Efek non-hematologis yang paling umum terkait dengan terapi pengobatan nilotinib yaitu ruam, mual, pruritus, dan sakit kepala. Selain itu, efek samping obat yang mungkin terjadi pula dari terapi nilotinib yaitu diare, musculoskeletal pain seperti kejang otot, nyeri sendi, dan nyeri otot.

Tabel 3. Hasil evaluasi Algoritma Naranjo terjadinya Musculoskeletal Pain pada pasien CML dengan kemoterapi nilotinib ( $\mathrm{n}$ total $=35$ pasien).

\begin{tabular}{ccc}
\hline Kategori & Jumlah & Presentase (\%) \\
\hline Doubtful & 22 & $62,86 \%$ \\
Possible & 7 & $20 \%$ \\
Probable & 6 & $17,14 \%$ \\
\hline
\end{tabular}

Pasien yang menerima nilotinib dapat mengalami intoleransi berupa terjadinya ADR, salah satunya yaitu musculoskeletal pain dengan grade yang berbeda-beda. Akan tetapi, pada penelitian ini tidak diukur skala nyeri untuk terjadinya musculoskeletal pain, sehingga tidak bisa mengetahui tingkat keparahan musculoskeletal pain yang terjadi. Apabila mengetahui skala nyeri dan tingkat keparahan musculoskeletal pain yang dialami, dapat dilakukan monitoring penatalaksanaan terapi musculoskeletal pain dengan lebih tepat. Diketahui secara luas bahwa toksisitas yang parah dapat menentukan perubahan atau gangguan dalam terapi. Begitu pula pada efek musculoskeletal pain yang tidak jarang juga ditemukan dalam kondisi yang ringan hingga parah (Jabbour et al., 2011). Secara umum, sebagian besar ADR yang terjadi selama terapi inhibitor $B C R-A B L$ dapat dikelola dengan penghentian atau pengurangan 
dosis serta dengan perawatan suportif (Wei et al., 2010). Pada penelitian Rosti, et al (2012), menyebutkan bahwa pasien dengan nilotinib dapat mengalami musculoskeletal pain hingga grade 3. Dimana penatalaksanaan pada toksisitas nilotinib dengan grade $\geq 3$ dapat dilakukan dengan penghentian pengobatan (Jabbour et al., 2011).

Pada penelitian ini pasien yang mengalami musculoskeletal pain diberikan terapi pengobatan untuk menangani efek musculoskeletal pain tersebut. Terapi yang digunakan yaitu obat golongan NSAIDs (Nonsteroidal Anti-inflammatory Drugs) dan golongan kortikosteroid. Pengobatan dengan NSAIDs dan kortikosteroid merupakan salah satu manajemen klinis musculoskeletal pain pada pasien CML dengan nilotinib. Dimana setelah diberikan pengobatan tersebut, pada penelitian ini terdapat 2 pasien yang masih mengalami musculoskeletal pain, sedangkan pada 11 pasien lainnya pengobatan tersebut sudah cukup untuk mengobati keluhan musculoskeletal pain. Pada penelitian yang dilakukan oleh Rosti, et al (2012), menjelaskan bahwa pasien yang mengalami musculoskeletal pain biasanya ringan dan mudah dikelola tanpa pengurangan atau interupsi nilotinib, dimana pengobatan dengan NSAIDs sudah dapat mengendalikan musculoskeletal pain yang terjadi. Keluhan musculoskeletal pain dapat dikelola dengan pengobatan NSAIDs dan apabila tidak ada perbaikan, maka pemberian kortikosteroid dosis rendah dapat dipertimbangkan (Kota \& Atallah, 2019). Hal tersebut juga dijelaskan pada penelitian Diab \& Schiffer (2019), yang menyatakan bahwa pasien yang mengalami musculoskeletal pain merespon pengobatan NSAIDs secara minimal dan memerlukan kortikosteroid jangka pendek untuk meringankannya.

\subsection{Pengaruh faktor-faktor terhadap terjadinya musculoskeletal pain dengan kemoterapi nilotinib}

\subsubsection{Analisis bivariat faktor terhadap musculoskeletal pain}

Analisis bivariat pada penelitian ini dilakukan antara faktor-faktor seperti usia, Indeks Masa Tubuh (IMT), dan riwayat Diabetes Mellitus (DM) terhadap ada tidaknya musculoskeletal pain.Analisis bivariat yang digunakan pada penelitian ini adalah uji Chi Squareatau uji Fisher karena analisis yang dilakukan pada penelitian termasuk dalam analisis komparatif kategorik tidak berpasangan. Setelah dilakukan uji bivariat, didapatkan hasil seperti yang tercantum pada Tabel 4. Berdasarkan hasil uji komparatif Fisher pada Tabel 4 didapatkan bahwa $p$ value usia dengan terjadinya musculoskeletal pain sebesar 0,220 ( $p$ > $0,05)$ yang menunjukkan bahwa tidak terdapat hubungan antara usia dengan terjadinya musculoskeletal pain. Faktor usia memiliki nilai OR sebesar 4,5 yang artinya bahwa risiko musculoskeletal pain lebih tinggi 4,5 kali pada kelompok usia > 35 tahun dibandingkan dengan kelompok usia 18 - 35 tahun. Interval Kepercayaan 95\% (IK 95\%) faktor usia yaitu 
0,48 - 42,50. Nilai IK 95\% mencakup angka 1 artinya dari data yang sudah ada belum dapat disimpulkan bahwa faktor usia yang diteliti benar-benar merupakan faktor risiko.

Hal ini tidak sesuai dengan penelitian yang dilakukan oleh Najafipour, et al (2017), yang menyatakan bahwa usia merupakan salah satu faktor yang memengaruhi secara signifikan terhadap peningkatan kejadian musculoskeletal pain. Tinjauan sistematis terkait musculoskeletal pain mengungkapkan bahwa orang berusia lebih dari 35 tahun sebagian besar lebih rentan terkena musculoskeletal pain. Hal tersebut dikarenakan pada orang yang berusia lebih tua maka kepadatan tulang dan kekuatan otot akan semakin rendah sehingga berpengaruh pada tingginya masalah tulang dan otot (Blyth \& Noguchi, 2017).

Pada faktor IMT dengan terjadinya musculoskeletal pain diperoleh $p$ value sebesar $0,032(p<0,05)$ yang menunjukkan bahwa terdapat hubungan antara usia dengan terjadinya musculoskeletal pain. Faktor IMT memiliki nilai OR sebesar 8,57 yang artinya bahwa risiko musculoskeletal pain lebih tinggi pada kelompok IMT $\geq 25 \mathrm{~kg} / \mathrm{m}^{2}$ dibandingkan dengan kelompok IMT $<25 \mathrm{~kg} / \mathrm{m}^{2}$. Interval Kepercayaan 95\% (IK 95\%) faktor IMT yaitu 1,3952,75. Nilai IK 95\% tersebut tidak mencakup angka 1, yang artinya pada populasi yang diwakili oleh sampel dapat disimpulkan bahwa benar faktor IMT merupakan faktor yang berhubungan dengan terjadinya musculoskeletal pain.Hal itu sesuai dengan penelitian yang dilakukan oleh Blümel, et al (2017), yang menyatakan bahwa pasien dengan nilai IMT $\geq 25$ $\mathrm{kg} / \mathrm{m}^{2}$ memiliki nilai risiko tertinggi terhadap terjadinya musculoskeletal pain. Penelitian yang dilakukan pada wanita obesitas diketahui $p$ value hasil uji bivariat menunjukkan bahwa pada wanita obesitas berhubungan signifikan dengan terjadinya musculoskeletal pain (Ogwumike et al, 2016). Pada penelitian Vincent, et al (2012), menyebutkan bahwa obesitas memengaruhi berbagai aktivitas sehari-hari dimana hal tersebut berhubungan dengan beban tubuh yang berat, sehingga dapat meningkatkan keluhan pada sistem muskuloskeletal.

Hasil uji komparatif Fisher pada Tabel 4 didapatkan $p$ value antara riwayat DM dengan terjadinya musculoskeletal pain sebesar 0,541 $(p>0,05)$ yang menunjukkan bahwa tidak terdapat hubungan antara riwayat DM dengan terjadinya musculoskeletal pain. Faktor riwayat DM memiliki nilai OR sebesar 3,82 yang artinya bahwa risiko musculoskeletal pain lebih tinggi 3,82 kali pada kelompok yang memiliki riwayat DM dibandingkan dengan kelompok yang tidak memiliki riwayat DM. Interval Kepercayaan 95\% (IK 95\%) faktor riwayat DM yaitu 0,31-46,93. Nilai IK 95\% mencakup angka 1 artinya dari data yang sudah ada belum dapat disimpulkan bahwa faktor usia yang diteliti benar-benar merupakan faktor risiko. Pada penelitian yang dilakukan oleh Molsted, et al (2012), menyatakan bahwa pasien dengan diabetes mellitus memiliki prevalensi musculoskeletal pain yang secara signifikan lebih tinggi dibandingkan pasien non diabetes mellitus. Analisis multivariat faktor risiko terhadap 
musculoskeletal pain. Pada Tabel 4 dapat diketahui variabel yang memiliki $p$ value $<0,25$ yaitu usia dan Indeks Masa Tubuh (IMT). Selanjutnya variabel tersebut dilakukan pengujian dengan menggunakan uji regresi logistik. Hasil analisis regresi logistik faktor-faktor terhadap terjadinya musculoskeletal pain dapat diamati pada Tabel 5.

Tabel 4. Hasil uji komparatif antara faktor-faktor terhadap ada tidaknya musculoskeletal pain (jumlah total pasien $=35$ ). Keterangan: $*$ menunjukkan faktor-faktor yang lolos uji regresi logistik. $\%=(\mathrm{n} / \Sigma) \times 100 \%$ dan $\mathrm{N}$ total $=$ jumlah total seluruh subyek penelitian dengan kemoterapi nilotinib.

\begin{tabular}{|c|c|c|c|c|c|c|c|c|c|}
\hline \multirow{3}{*}{\multicolumn{2}{|c|}{ Faktor-Faktor }} & \multicolumn{4}{|c|}{ Musculoskeletal Pain } & \multirow{3}{*}{$p$ value } & \multirow{3}{*}{ OR } & \multirow{2}{*}{\multicolumn{2}{|c|}{ IK (95\%) }} \\
\hline & & \multicolumn{2}{|c|}{$\mathrm{Ya}(\mathrm{N}=13)$} & \multicolumn{2}{|c|}{ Tidak(N = 22) } & & & & \\
\hline & & $\mathbf{n}$ & $\%$ & $\mathbf{n}$ & $\%$ & & & Min & Maks \\
\hline \multirow[b]{2}{*}{ Usia } & $>35$ tahun & 12 & $42,9 \%$ & 16 & $57,1 \%$ & \multirow[b]{2}{*}{$0,220 *$} & \multirow[b]{2}{*}{4,50} & \multirow[b]{2}{*}{0,48} & \multirow[b]{2}{*}{42,50} \\
\hline & $\begin{array}{l}18-35 \\
\text { tahun }\end{array}$ & 1 & $14,3 \%$ & 6 & $85,7 \%$ & & & & \\
\hline \multirow{2}{*}{ IMT } & $\begin{array}{c}\geq 25 \\
\mathrm{~kg} / \mathrm{m}^{2}\end{array}$ & 6 & $75,0 \%$ & 2 & $25,0 \%$ & \multirow{2}{*}{$0,032^{*}$} & \multirow{2}{*}{8,57} & \multirow{2}{*}{1,39} & \multirow{2}{*}{52,75} \\
\hline & $\begin{array}{c}<25 \\
\mathrm{~kg} / \mathrm{m}^{2}\end{array}$ & 7 & $25,9 \%$ & 20 & $74,1 \%$ & & & & \\
\hline \multirow{2}{*}{$\begin{array}{l}\text { Riwaya } \\
\text { t DM }\end{array}$} & $\mathrm{Ya}$ & 2 & $66,7 \%$ & 1 & $33,3 \%$ & \multirow{2}{*}{0,541} & \multirow{2}{*}{3,82} & \multirow{2}{*}{0,31} & \multirow{2}{*}{46,93} \\
\hline & Tidak & 11 & $34,4 \%$ & 21 & $65,6 \%$ & & & & \\
\hline \multicolumn{2}{|c|}{ Total } & 13 & $37,1 \%$ & 22 & $62,9 \%$ & & & & \\
\hline
\end{tabular}

Nilai Nagelkerke $R$ Square dapat digunakan untuk melihat kemampuan variabel independen dalam menjelaskan variabel dependen (Tabel 5). Variabel independen dalam analisis ini yaitu usia dan IMT, sedangkan variabel dependen yaitu terjadinya musculoskeletal pain. Nilai Nagelkerke $R$ Square pada langkah pertama sebesar 0,248 yang menunjukkan bahwa kemampuan faktor usia dan IMT dalam menjelaskan terjadinya musculoskeletal pain adalah sebesar $24,8 \%$. Hal itu berarti masih terdapat $75,2 \%$ dari faktor lain yang mungkin lebih dapat menjelaskan terjadinya musculoskeletal pain. Faktor lain yang mungkin dapat menjelaskan yaitu faktor penggunaan obat lain. Penggunaan obat lain yang dapat menyebabkan musculoskeletal pain yaitu penggunaan obat golongan statin. Selain penggunaan obat lain faktor riwayat penggunaan imatinib juga dapat menjelaskan terjadinya musculoskeletal pain. Hal itu dikarenakan bahwa efek samping imatinib dilaporkan lebih tinggi daripada nilotinib termasuk terjadinya musculoskeletal pain, dimana penghentian imatinib dan beralih ke nilotinib menyebabkan sindrom penghentian TKI yang lebih parah berupa musculoskeletal pain (Bhalla et al, 2016).

Langkah pertama pada hasil analisis regresi logistic factor-faktor terhadap terjadinya Musculoskeletal Pain di RSUD Dr. Moewardi menunjukkan hasil $p$ value yang paling besar adalah faktor usia dengan $p$ value 0,426 ( $p>0,05)$. Hal itu menunjukkan bahwa variabel usia tidak berpengaruh secara signifikan terhadap terjadinya musculoskeletal pain. Nilai OR pada 
analisis regresi logistik digunakan dalam menggambarkan hasil akhir dari faktor risiko terjadinya musculoskeletal pain. Analisis pada faktor usia memiliki nilai OR sebesar 2,57 yang artinya bahwa odds kelompok usia >35 tahun untuk terjadinya musculoskeletal pain adalah 2,57 kali odds kelompok usia 18 - 35 tahun untuk terjadinya musculoskeletal pain. Faktor yang berpengaruh signifikan terhadap terjadinya musculoskeletal pain pada penelitian ini yaitu Indeks Masa Tubuh (IMT) dengan $p$ value $0,041(p<0,05)$. Pada analisis ini faktor IMT memiliki nilai OR sebesar 7 yang artinya bahwa odds kelompok IMT $\geq 25 \mathrm{~kg} / \mathrm{m}^{2}$ untuk terjadinya musculoskeletal pain adalah 7 kali odds kelompok IMT $<25 \mathrm{~kg} / \mathrm{m}^{2}$ untuk terjadinya musculoskeletal pain. Interval Kepercayaan 95\% (IK 95\%) faktor IMT pada analisis ini yaitu 1,09-45,16. Nilai IK 95\% tersebut tidak mencakup angka 1, sehingga dapat diinterpretasikan bahwa faktor IMT merupakan faktor risiko dimana pasien dengan nilai IMT $\geq 25 \mathrm{~kg} / \mathrm{m}^{2}$ mempunyai kemungkinan 7 kali untuk mengalami musculoskeletal pain dibandingkan dengan pasien yang memiliki nilai IMT $<25 \mathrm{~kg} / \mathrm{m}^{2}$.

Tabel 5. Hasil analisis regresi logistik faktor-faktor terhadap terjadinya Musculoskeletal Pain di RSUD Dr. Moewardi.

\begin{tabular}{|c|c|c|c|c|c|c|c|}
\hline \multirow{2}{*}{$\begin{array}{c}\text { Langka } \\
\mathbf{h}\end{array}$} & \multirow{2}{*}{$\begin{array}{c}\text { Variabe } \\
1\end{array}$} & \multirow{2}{*}{$\begin{array}{c}\text { Nagelkerk } \\
\text { e } R \\
\text { Square } \\
\end{array}$} & \multirow[b]{2}{*}{ B } & \multirow[b]{2}{*}{ P value } & \multirow[b]{2}{*}{ OR } & \multicolumn{2}{|c|}{ IK 95\% } \\
\hline & & & & & & Min & Maks \\
\hline \multirow{3}{*}{1} & Usia & \multirow{3}{*}{0,248} & 0,944 & 0,426 & 2,57 & 0,25 & 26,25 \\
\hline & IMT & & 1,946 & 0,041 & 7 & 1,09 & 45,16 \\
\hline & $\begin{array}{c}\text { Konstant } \\
\text { a }\end{array}$ & & $-1,792$ & 0,097 & 0,17 & & \\
\hline
\end{tabular}

Hal ini sesuai dengan penelitian yang dilakukan oleh MacLellan, et al (2017), yang menyatakan bahwa terdapat hubungan yang sangat signifikan antara obesitas dan musculoskeletal pain. Kelebihan berat badan (IMT $\geq 25 \mathrm{~kg} / \mathrm{m}^{2}$ ) dengan terjadinya musculoskeletal pain merupakan suatu kondisi umum yang sering terjadi. Obesitas sangat berhubungan dengan terjadinya musculoskeletal pain dimana prevalensi kejadian musculoskeletal pain semakin meningkat pada populasi yang obesitas (Peltonen et al, 2003). Sehingga berdasarkan Tabel 5 hasil analisis multivariat, dapat dibuat persamaan analisis regresi logistik persamaan 1 .

$$
\mathrm{y}=(-1,792)+0,944 \times \text { Usia }+1,946 \times \text { Indeks Masa Tubuh }
$$

Persamaan 1. Analisis regresi logistic. Keterangan: Usia ( $>35$ tahun atau $18-35$ tahun), Indeks Masa Tubuh $\left(\geq 25 \mathrm{~kg} / \mathrm{m}^{2}\right.$ atau $\left.<25 \mathrm{~kg} / \mathrm{m}^{2}\right)$.

Hasil dari penelitian ini menunjukan faktor risiko yang memengaruhi secara signifikan terhadap terjadinya musculoskeletal pain pada pasien CML dengan kemoterapi nilotinib di RSUD Dr. Moewardi adalah faktor Indeks Masa Tubuh (IMT) dengan $p$ value sebesar 0,041. Nilai OR sebesar 7 dengan Interval Kepercayaan 95\% (IK 95\%) yaitu 1,09 - 45,16 yang 
artinya bahwa pasien dengan Indeks Masa Tubuh (IMT) $\geq 25 \mathrm{~kg} / \mathrm{m}^{2}$ memiliki kemungkinan 7 kali untuk mengalami musculoskeletal pain dibanding pasien dengan Indeks Masa Tubuh (IMT) $<25 \mathrm{~kg} / \mathrm{m}^{2}$. Faktor usia dan riwayat Diabetes Mellitus (DM) tidak berpengaruh secara signifikan terhadap terjadinya musculoskeletal pain.

\section{Kesimpulan}

Frekuensi terjadinya musculoskeletal pain pada pasien Chronic Myeloid Leukemia (CML) dengan kemoterapi nilotinib di RSUD Dr. Moewardi yaitu sebesar 37,1\% (13 pasien) dari total jumlah pasien sebanyak 35 pasien dengan faktor yang berpengaruh secara signifikan yaitu faktor Indeks Masa Tubuh (IMT), sedangkan faktor usia dan riwayat Diabetes Mellitus (DM) tidak berpengaruh secara signifikan terhadap terjadinya musculoskeletal pain.

\section{Ucapan Terimakasih}

Terimakasih kepada berbagai pihak di RSUD Dr. Moewardi Surakarta yang telah memberikan izin untuk melakukan penelitian dan memperoleh data untuk mendukung penelitian ini.

\section{Deklarasi Konflik Kepentingan}

Semua penulis menyatakan tidak ada konflik kepentingan terhadap naskah ini.

\section{Daftar Pustaka}

Bhalla, S., Tremblay, D., and Mascarenhas, J. (2016). Discontinuing Tyrosine Kinase Inhibitor Therapy in Chronic Myelogenous Leukemia: Current Understanding and Future Directions. Clinical Lymphoma Myeloma and Leukemia, 16(9), 488-494. 10.1016/j.clml.2016.06.012.

Blümel, J. E., Arteaga, E., Mezones-Holguín, E., Zúñiga, M. C., Witis, S., Vallejo, M. S., Tserotas, K., Sánchez, H., Onatra, W., Ojeda, E., Mostajo, D., Monterrosa, A., Lima, S., Martino, M., Hernández-Bueno, J. A., Gómez, G., Espinoza, M. T., Flores, D., Chedraui, P., Calle, A., Bravo, L.M., Benítez, Z., Bencosme, A., and Baron, G. (2017). Obesity is associated with a higher prevalence of musculoskeletal pain in middle-aged women. Gynecological Endocrinology, 33(5), 378-382. 10.1080/09513590.2016.1269741.

Blyth, F. M., and Noguchi, N. (2017). Chronic musculoskeletal pain and its impact on older people. Best Practice \& Research Clinical Rheumatology, 31(2), 160-168. 10.1016/j.berh.2017.10.004.

Breccia, M., Loglisci, G., Salaroli, A., Serrao, A., Mancini, M., Diverio, D., Latagliata, R., and Alimena, G. (2013). Delayed cytogenetic and major molecular responses associated to increased BMI at baseline in chronic myeloid leukemia patients treated with imatinib. Cancer Letters, 333(1), 32-35. 10.1016/j.canlet.2012.12.018.

Cortes, J. E., Lipton, J. H., Miller, C. B., Busque, L., Akard, L. P., Pinilla-Ibarz, J., Keir, C., Warsi, G., Lin, F. P., and Mauro, M. J. (2016). Evaluating the Impact of a Switch to Nilotinib on Imatinib-Related Chronic Low-Grade Adverse Events in Patients With CML-CP: The ENRICH Study. Clinical Lymphoma Myeloma and Leukemia, 16(5), 286-296. 10.1016/j.clml.2016.02.002.

Cortes, J., Huynh, L., Mendelson, E., Brandt, P., Dalal, D., DerSarkissian, M., Cortina, D., Narkhede, S., and Sheng Duh, M. (2020). Treatment patterns and deep molecular response in chronic phase - chronic myeloid leukemia patients treated with second-line 
nilotinib or dasatinib: A multi-country retrospective chart review study. Leukemia \& Lymphoma, 61(1), 98-107. 10.1080/10428194.2019.1644332.

Dahlan, M. S. (2011). Statistik untuk Kedokteran dan Kesehatan, Penerbit Salemba.

Diab, M., and Schiffer, C. A. (2019). The spectrum of musculoskeletal symptoms in patients with chronic myeloid leukemia after stopping tyrosine kinase inhibitors. Leukemia Research, 79, 1-2. 10.1016/j.leukres.2019.02.001.

Hiwase, D., Tan, P., D’Rozario, J., Taper, J., Powell, A., Irving, I., Wright, M., Branford, S., Yeung, D. T., Anderson, L., Gervasio, O., Levetan, C., Roberts, W., Solterbeck, A., Traficante, R., and Hughes, T. (2018). Efficacy and safety of nilotinib $300 \mathrm{mg}$ twice daily in patients with chronic myeloid leukemia in chronic phase who are intolerant to prior tyrosine kinase inhibitors: Results from the Phase IIIb ENESTswift study. Leukemia Research, 67, 109-115. 10.1016/j.leukres.2018.02.013.

Holyoake, T. L., and Vetrie, D. (2017). The chronic myeloid leukemia stem cell: Stemming the tide of persistence. Blood, 129(12), 1595-1606. 10.1182/blood-2016-09-696013.

Hussain, S., andShaikh, M.U. (2015). Response and Adverse Effects of Nilotinib in Imatinibresistant Chronic Myeloid Leukemia Patients: Data From a Developing Country. Clinical Therapeutics, 37(11), 2449-2457.10.1016/j.clinthera.2015.08.026.

Jabbour, E., Deininger, M., and Hochhaus, A. (2011). Management of adverse events associated with tyrosine kinase inhibitors in the treatment of chronic myeloid leukemia. Leukemia, 25(2), 201-210. 10.1038/leu.2010.215.

Janssen, L., Frambach, S. J. C. M., Allard, N. A. E., Hopman, M. T. E., Schirris, T. J. J., Voermans, N. C., Rodenburg, R. J., Blijlevens, N. M. A., and Timmers, S. (2019). Skeletal muscle toxicity associated with tyrosine kinase inhibitor therapy in patients with chronic myeloid leukemia. Leukemia, 33(8), 2116-2120. 10.1038/s41375-0190443-7.

Kim, D.-W., Banavali, S. D., Bunworasate, U., Goh, Y.-T., Ganly, P., Huang, H., Irving, I., Jootar, S., Goh, H.-G., Koh, L.-P., Li, W., Naoe, T., Ng, S.-C., Purushotaman, V., Reksodiputro, H., Shih, L.-Y., Tang, J.-L., Tojo, A., Wang, J., and Wong, R. (2010). Chronic myeloid leukemia in the Asia-Pacific region: Current practice, challenges and opportunities in the targeted therapy era. Leukemia Research, 34(11), 1459-1471. 10.1016/j.leukres.2010.03.033.

Kota, V., and Atallah, E. (2019). Musculoskeletal Pain in Patients With Chronic Myeloid Leukemia After Tyrosine Kinase Inhibitor Therapy Cessation. Clinical Lymphoma Myeloma and Leukemia, 19(8), 480-487. 10.1016/j.clml.2019.05.007.

MacLellan, G. A., Dunlevy, C., O’Malley, E., Blake, C., Breen, C., Gaynor, K., Wallace, N., Yoder, R., Casey, D., Mehegan, J., O'Shea, D., and Fullen, B. M. (2017). Musculoskeletal pain profile of obese individuals attending a multidisciplinary weight management service: PAIN, 158(7), 1342-1353. 10.1097/j.pain.0000000000000918.

Martino, B., Mammì, C., Labate, C., Rodi, S., Ielo, D., Priolo, M., Postorino, M., Tripepi, G., Ronco, F., Laganà, C., Musolino, C., Greco, M., La Nasa, G., and Caocci, G. (2017). Genetic risk of prediabetes and diabetes development in chronic myeloid leukemia patients treated with nilotinib. Experimental Hematology, 55, 71-75. 10.1016/j.exphem.2017.07.007.

Merashli, M., Chowdhury, T. A., and Jawad, A. S. M. (2015). Musculoskeletal manifestations of diabetes mellitus. QJM, 108(11), 853-857. 10.1093/qjmed/hcv106.

Molsted, S., Tribler, J., and Snorgaard, O. (2012). Musculoskeletal pain in patients with type 2 diabetes. Diabetes Research and Clinical Practice, 96(2), 135-140. 10.1016/j.diabres.2011.12.022.

Najafipour, H., Sadeghigoghari, M., Kordestani, Z., Naghibzadeh Tahami, A., and Ghavipisheh, M. (2017). Prevalence of the Musculoskeletal Pain Syndrome and Its Associated Factors in People Between 15 and 80 Years in Kerman: A Population-based 
Study on 1700 Individuals. Iranian Red Crescent Medical Journal, 19(4). 10.5812/ircmj.45084.

Nakamae, H., Shibayama, H., Kurokawa, M., Fukuda, T., Nakaseko, C., Kanda, Y., Nagai, T., Ohnishi, K., Maeda, Y., Matsuda, A., Amagasaki, T., and Yanada, M. (2011). Nilotinib as frontline therapy for patients with newly diagnosed $\mathrm{Ph}+$ chronic myeloid leukemia in chronic phase: Results from the Japanese subgroup of ENESTnd. International Journal of Hematology, 93(5), 624-632. 10.1007/s12185-011-0841-8.

Ogwumike, O. O., Adeniyi, A. F., and Orogbemi, O. O. (2016). Musculoskeletal pain among postmenopausal women in Nigeria: Association with overall and central obesity. Hong Kong Physiotherapy Journal, 34, 41-46. 10.1016/j.hkpj.2015.06.001.

Peltonen, M., Lindroos, A. K., and Torgerson, J. S. (2003). Musculoskeletal pain in the obese: A comparison with a general population and long-term changes after conventional and surgical obesity treatment: Pain, 104(3), 549-557. 10.1016/S0304-3959(03)00091-5.

Pulte, E. D., Wroblewski, T., Bloomquist, E., Tang, S., Farrell, A., Deisseroth, A., McKee, A. E., and Pazdur, R. (2019). U.S. Food and Drug Administration Benefit-Risk Assessment of Nilotinib Treatment Discontinuation in Patients with Chronic Phase Chronic Myeloid Leukemia in a Sustained Molecular Remission. The Oncologist, 24(5). 10.1634/theoncologist.2018-0759.

Reksodiputro A, H. (2015). Epidemiology Study and Mutation Profile of Patients with Chronic Myeloid Leukemia (CML) in Indonesia. Journal of Blood Disorders and Transfusion, 06(03). 10.4172/2155-9864.1000271.

Rosti, G., Castagnetti, F., Gugliotta, G., Palandri, F., and Baccarani, M. (2012). Physician's guide to the clinical management of adverse events on nilotinib therapy for the treatment of CML. Cancer Treatment Reviews, 38(3), 241-248. 10.1016/j.ctrv.2011.07.004.

Signorovitch, J., Ayyagari, R., Reichmann, W. M., Wu, E. Q., and Chen, L. (2014). Major molecular response during the first year of dasatinib, imatinib or nilotinib treatment for newly diagnosed chronic myeloid leukemia: A network meta-analysis. Cancer Treatment Reviews, 40(2), 285-292. 10.1016/j.ctrv.2013.09.004.

Vincent, H. K., Raiser, S. N., and Vincent, K. R. (2012). The aging musculoskeletal system and obesity-related considerations with exercise. Ageing Research Reviews, 11(3), 361373. 10.1016/j.arr.2012.03.002.

Wei, G., Rafiyath, S., and Liu, D. (2010). First-line treatment for chronic myeloid leukemia: Dasatinib, nilotinib, or imatinib. Journal of Hematology \& Oncology, 3(1), 47. 10.1186/1756-8722-3-47.

Widyastuti, R., Louisa, M., Rinaldi, I., Nova, R., Instiaty, I., and Priambodo, R. (2020). Mutation Analysis of ABL1 Gene and its Relation to the Achievement of Major Molecular Response in Indonesian Chronic Myeloid Leukemia Patients. Current Pharmacogenomics and Personalized Medicine, 17(1), 48-54. 10.2174/1875692117666190925115852.

Williams, E. P., Mesidor, M., Winters, K., Dubbert, P. M., and Wyatt, S. B. (2015). Overweight and Obesity: Prevalence, Consequences, and Causes of a Growing Public Health Problem. Current Obesity Reports, 4(3), 363-370. 10.1007/s13679-015-0169-4.

Yu, L., Huang, X., Gale, R. P., Wang, H., and Jiang, Q. (2019). Variables associated with patient-reported symptoms in persons with chronic phase chronic myeloid leukemia receiving tyrosine kinase inhibitor therapy: Medicine, 98(48), e18079. 10.1097/MD.0000000000018079.

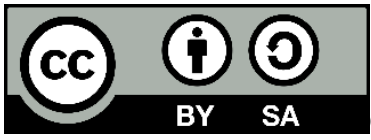

2021 by the authors. Submitted for possible open access publication under the terms and conditions of the Creative Commons Attribution-ShareAlike 4.0 International (CC BY-SA 4.0) license (https://creativecommons.org/licenses/by-sa/4.0/). 